\title{
The Multiple Impacts of the COVID-19 Pandemic on China's Oil Security and the Rising Green Opportunities
}

\author{
Haiyu Xie ${ }^{1}$ \\ ${ }^{1}$ School of Social Sciences and Technology, Technical University of Munich, Munich, Germany \\ Correspondence: Haiyu Xie, School of Social Sciences and Technology, Technical University of Munich, \\ Munich, Germany. E-mail: haiyuxie@zedat.fu-berlin.de
}

Received: September 30, 2021

Accepted: November 1, $2021 \quad$ Online Published: November 5, 2021

doi:10.5539/ibr.v14n12p76

URL: https://doi.org/10.5539/ibr.v14n12p76

\begin{abstract}
The COVID-19 pandemic has seriously challenged the global oil market, and coronavirus-induced oil prices crash, oil demand decline and global economic recession affect China's oil supply as well. China has high oil vulnerability due to its rising oil import dependency which aggravates Beijing's concerns about oil security, despite at a time of the pandemic-induced oil oversupply. This study uses the SWOT analytical model to identify the strengths, weaknesses, opportunities and threats in China's oil sector, and the changes in opportunities and threats caused by the COVID-19 pandemic. The pandemic has brought multiple impacts to China's oil security. Results from the analysis show that the existing opportunities such as oil investments in the Belt and Road Initiative (BRI) and domestic upstream opening-up have been weakened; new threats that the uncertainty over global oil demand-supply and decrease in global upstream investments have emerged; opportunities that an increase in domestic strategic petroleum reserve (SPR) and low-carbon development are rising amid the pandemic. Notably, the COVID-19 pandemic has demonstrated the vulnerability of the global oil market to systemic risks and accelerated the transition to renewable energy.
\end{abstract}

Keywords: COVID-19 pandemic, China, oil security, NOCs, SWOT analysis

\section{Introduction}

The COVID-19 pandemic has caused more disruption to the energy sector than any other event in recent history, triggering a considerable shock to international crude prices in 2020 and leaving uncertainties for the global oil market for years to come (IEA, 2020c). There were a few historical record-breaking moments: the international oil prices slumped, and the negative oil prices appeared for the first time in history; Organization of Petroleum Exporting Countries (OPEC) has suffered the largest reduction in production $(9.7 \mathrm{mb} / \mathrm{d})$ in history, and the decline in world oil supply $(6.6 \mathrm{mb} / \mathrm{d})$ was also the largest in history (OPEC, 2020). As shown in Figure 1, the supply and demand of the world oil market in 2020 were severely imbalanced, and the average annual Brent crude price was $\$ 41.9$ a barrel, with a 34 per cent year-on-year decrease (Statista, 2021). According to BP, the global oil consumption in 2020 fell by a record $9.1 \mathrm{mb} / \mathrm{d}$, or 9.3 per cent, to its lowest level since 2011(BP, 2021).

Oil demand in China suffered the most in the first quarter of 2020, with a year-on-year fall of $1.8 \mathrm{mb} / \mathrm{d}$ (IEA, 2020b). Notably, China experienced the earliest but also the shortest lockdown. Consequently, its oil demand rebounded quickly and by June 2020 it had reached 90 per cent of its pre-pandemic level (Xu,Kelly \&Obayashi, 2020). Meanwhile, considering its high dependence on foreign oil, China is very vulnerable and sensitive to any pandemic-induced changes in the global oil market. The national oil companies (NOCs) suffered losses due to the low oil demand and oil price decline, forcing them to adjust the development strategies in response to the pandemic-induced challenges.

The impacts of the COVID-19 are far-reaching, and among them, one of the significant impacts seemed to be on the acceleration of peaking oil demand (Froggatt \&Quiggin, 2021). On the one hand, the oil companies pursue greater returns and seek to reduce losses by investing in low-carbon development. On the other hand, the green recovery approaches implemented by major powers such as the EU will accelerate the energy transition, reshape the energy sector fundamentally and trigger new climate policies. It is calculated that as of 23 June 2021, over \$271.6 trillion has been distributed to COVID-19 economic stimulus packages and the green-led recoveries are the priorities for most governments and international finance institutions (Cornish, 2021). In September 2020, Chinese President Xi Jinping, at the 75th United Nations General Assembly, announced that China would 
increase its Intended Nationally Determined Contributions (Note 1) and committed to achieve the targets of carbon peak by 2030 and carbon neutrality by 2060 . Accordingly, accelerated energy transition plans at all levels and in different energy sectors are proposed and implemented, as well as the green recovery plans against the pandemic at home and abroad.

This study is organized as follows. Section 2 introduces the SWOT analytical model. Section 3 outlines the strengths and weaknesses of China's oil sector, and the opportunities and threats to China's oil security. Section 4 discusses the altered SWOT model caused by the pandemic, with existing opportunities weakened, new threats emerged and new opportunities arising. Section 5 concludes the study.

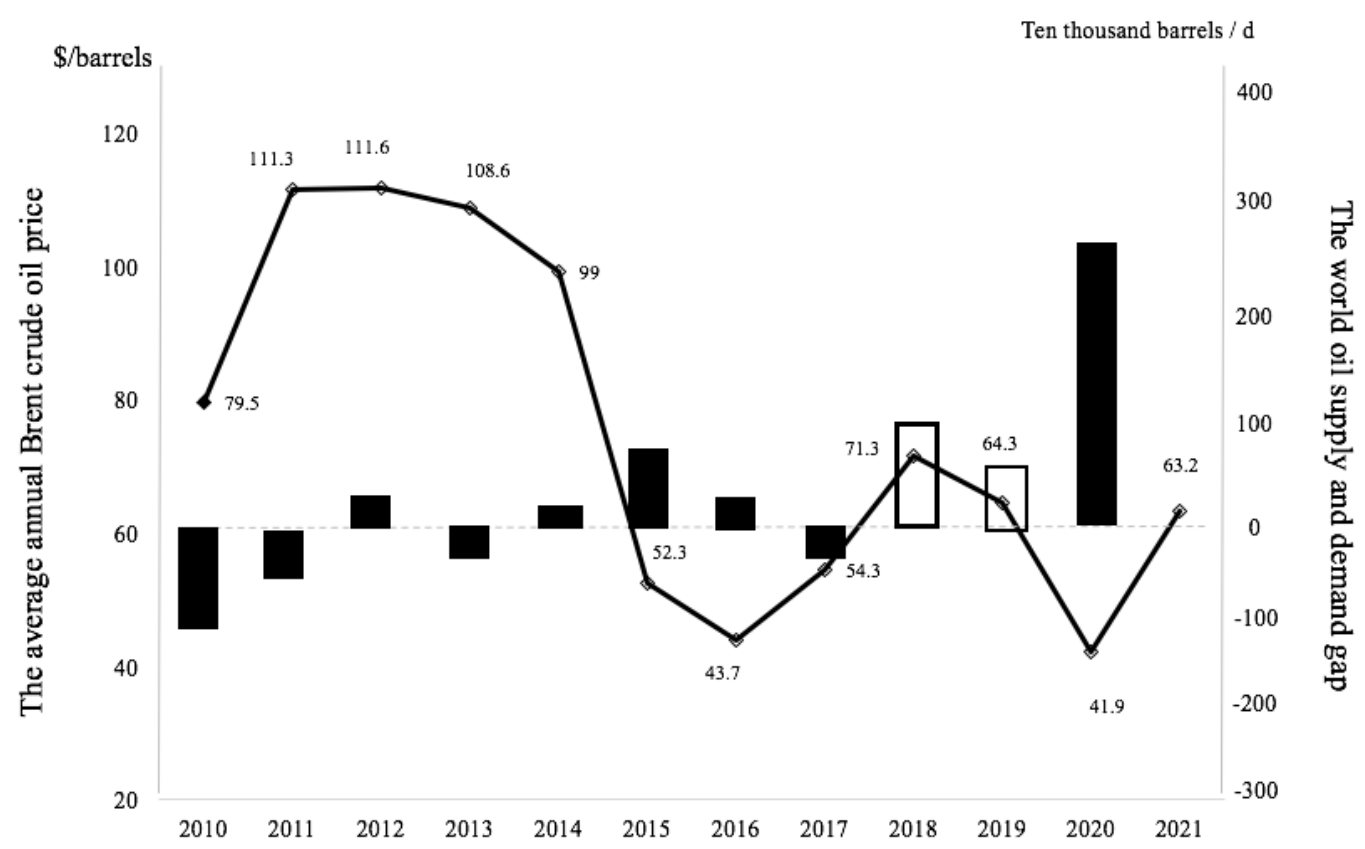

Figure 1. The world oil supply-demand gap and average annual Brent crude price 2010-2021

Note: As of 07 June, 2021.

Data source: Statista and IEA

\section{The SWOT Analytical Framework}

SWOT analysis originates from the field of economic analysis and later it extends to various sectors including energy management. SWOT refers to Strengths, Weaknesses, Opportunities and Threats. It is a structural tool that offers information to identify the internal and external factors that promote or hinder the development of an organization or industry (Irfan,Hao,Panjwani,Khan,Chandio \&Li, 2020). It is also one of the most important tools for adapting the strengths and weaknesses of an organization to the opportunities and threats it faces (Shirody, 2016). Among these, strengths and weaknesses are the advantages and disadvantages of a project or business, while opportunities and threats are the elements within the environment that promote or hinder the successful implementation of the project (Dess, 2018). To date, the SWOT analysis approach has been used in various fields concerning the energy sector like renewable energy development, assessment of energy technologies, and energy management and strategic planning (Markovska,Taseska \&Pop-Jordanov, 2009; Jaber,Elkarmi,Alasis \&Kostas, 2015), but it is rarely used in the existing literature to assess China's oil sector.

In this study, the SWOT analysis model is utilized to identify strengths, weaknesses, threats and opportunities of China's oil sector and examine the pandemic-induced changes of the opportunities and threats. Empirically, the SWOT model contributes to formulating counteractive measures to maximize opportunities and minimize threats, and thus the corresponding solutions that China could take to deal with the threats and challenges caused by the pandemic will also be reflected in the SWOT analysis matrix.

\section{SWOT Analysis of China's Oil Sector}

A widely accepted definition of energy security is "the availability of sufficient energy supplies at affordable 
prices" (Yergin, 2006). The International Energy Agency (IEA) defines energy security as the uninterrupted availability of energy sources at an affordable price (IEA, 2019a). Based on these, this study believes that oil security refers to the uninterrupted and sufficient oil supply at reasonable prices.

The three major NOCs, China National Petroleum Corporation (CNPC), China Petroleum and Chemical Corporation (Sinopec) and China National Offshore Oil Corporation (CNOOC), are the main guarantee for China's oil security through their overseas oil investments and exploration and production (E\&P). Also, the NOCs ensure China's oil supply by enhancing domestic oil output and improving oil extraction technologies. As state-owned enterprises, the NOCs serve the national energy security and strategic development, and as autonomous economic actors, the NOCs pursue corporate interests, which enable the NOCs at the forefront to enhance China's oil development and ensure its oil security.

Table 1. China's continental oil pipelines and sea lanes

\begin{tabular}{|c|c|c|c|c|c|}
\hline $\begin{array}{l}\text { Origin of } \\
\text { pipeline }\end{array}$ & $\begin{array}{l}\text { Name of } \\
\text { pipeline }\end{array}$ & $\begin{array}{c}\text { Capacity } \\
\text { /year }\end{array}$ & $\begin{array}{r}\text { Total } \\
\text { length }\end{array}$ & Details & Advantages \\
\hline Kazakhstan & $\begin{array}{l}\text { Kazakhstan- } \\
\text { China oil } \\
\text { pipeline }\end{array}$ & $\begin{array}{l}20 \\
\text { million } \\
\text { tons }\end{array}$ & $2798 \mathrm{~km}$ & $\begin{array}{l}\text { It started } \\
\text { operations } \\
\text { in } 2009 .\end{array}$ & $\begin{array}{l}\text { 1. Reduce China's dependence on } \\
\text { Middle East oil; } \\
\text { 2. Make China's oil supply routes } \\
\text { safer; } \\
\text { 3. Obtain long-term and stable } \\
\text { crude oil supply. }\end{array}$ \\
\hline Myanmar & $\begin{array}{l}\text { Myanmar- } \\
\text { China oil } \\
\text { pipeline }\end{array}$ & $\begin{array}{l}22 \\
\text { million } \\
\text { tons }\end{array}$ & $771 \mathrm{~km}$ & $\begin{array}{l}\text { It started } \\
\text { operation in } \\
\text { May } 2017 .\end{array}$ & $\begin{array}{l}\text { It mainly transports the crude oil } \\
\text { purchased from the Middle East by } \\
\text { land, avoiding the Strait of } \\
\text { Malacca, greatly shortening the } \\
\text { transportation mileage and cost of } \\
\text { some Middle East crude oil. }\end{array}$ \\
\hline \multirow{2}{*}{ Russia } & \multirow{2}{*}{$\begin{array}{l}\text { Russia- } \\
\text { China oil } \\
\text { pipeline }\end{array}$} & $\begin{array}{l}15 \\
\text { million } \\
\text { tons }\end{array}$ & $\begin{array}{l}999.04 \\
\mathrm{~km}\end{array}$ & $\begin{array}{l}\text { The first } \\
\text { pipeline } \\
\text { started } \\
\text { operation in } \\
2011 \text {. }\end{array}$ & \multirow{2}{*}{$\begin{array}{l}\text { 1. Reduce costs and raise the } \\
\text { efficiency of China's oil imports } \\
\text { from Russia, which had previously } \\
\text { relied on rail; } \\
2 \text {. Meet the diversification strategy } \\
\text { of China's petroleum supply and } \\
\text { ensure energy security. }\end{array}$} \\
\hline & & $\begin{array}{l}15 \\
\text { million } \\
\text { tons }\end{array}$ & $941.8 \mathrm{~km}$ & $\begin{array}{l}\text { The second } \\
\text { pipeline } \\
\text { started } \\
\text { operation in } \\
2018 \text {. }\end{array}$ & \\
\hline Sea lanes & $\begin{array}{l}\text { Malacca } \\
\text { Strait; } \\
\text { Pacific }\end{array}$ & & & & $\begin{array}{l}\text { Maritime transportation is the } \\
\text { lowest-cost way to transport oil } \\
\text { over long distances. }\end{array}$ \\
\hline
\end{tabular}

Source: Adapted by the author from Guo et al. (2019) and Tunsjø (2013)

\subsection{Analysis of Strengths}

\subsubsection{Financial and Diplomatic Supports from the Central Government}

As China relies on its NOCs to ensure sufficient oil supply, the central government provides financial and diplomatic support for the NOCs' oil development and production activities. The Chinese policy banks, which are the main force in China's global energy finance, drive the NOCs' overseas oil exploration and investments by offering a large amount of funds (Kong \&Gallagher, 2017). For example, the policy banks provided $\$ 225$ billion energy financial support between 2000 and 2017, of which over 70 per cent flowed to the NOCs' fossil fuels projects which contributed to easing the domestic energy shortage (Kong, 2019). It has been demonstrated that the policy banks did help the NOCs' international expansion and thus the NOCs were equipped with competitive advantages in overseas oil mergers and acquisitions (Patey, 2014).

Beijing also provides diplomatic support for the NOCs' overseas oil exploration and investments. High-level official visits, partnership establishment, foreign aid and even military arms transfer are conducted to oil-rich 
countries to ensure China's sufficient oil import and the NOCs' local investment opportunities. Therefore, "petroleum diplomacy", which refers to the combination of diplomacy and China's global hunt for oil, has become one of the significant features of China's foreign policy (Kong, 2010). Actually, almost all the major oil deals of the NOCs are inseparable from the central government's explicit diplomatic support through the latter's direct negotiations with the host governments (Andrews-Speed \&Dannreuther, 2013).

\subsubsection{Pipelines as Alternative Energy Corridors}

Diversification of energy corridors is one of the considerations to ensure energy security. It is believed that the investments in pipelines to deliver oil from neighboring oil exporters like Kazakhstan and "bypass" the high-risk routes such as the Malacca Strait could reduce the reliance on seaborne oil supplies and protect China's oil imports from potential supply disruptions, thereby enhancing China's oil security (Erickson \&Collins, 2010). For example, the Myanmar-China oil pipeline was proposed to reduce China's reliance on Malacca and act as a "backdoor" supply line (Yang, 2004). Currently, there are three continental pipelines, the Kazakhstan-China, the Myanmar-China and the Russia-China oil pipeline, connecting China and its energy partners (Xie, 2021). (See Table 1) The cross-border oil pipelines will be an alternative when the seaborne oil shipments are interrupted by wars or blockade. As the continental pipelines contribute to minimizing the transportation risks and threats, they are regarded as the insurance of China's oil security.

\subsection{Analysis of Weaknesses}

\subsubsection{Lack of Domestic Oil Resources and High Domestic Oil Production Cost}

The distinctive feature of China's energy structure is "more coal, less gas, and lack of oil", which indicates the oil resource constraints of China (Zhu \&Wang, 2020). As of the end of 2019, the proven oil reserve of China was 26.2 billion barrels, ranking 13th in the world and accounting for 1.5 per cent of the total world's oil reserves, amounting to only about 18 years of production in reserve (BP, 2020). Since the 1980s, the share of crude oil in domestic energy production has been declining. (See Figure 2) Meanwhile, the break-even point of crude oil extraction in most oil fields in China is between $\$ 50$ and $\$ 60$ per barrel (Deng, 2020), higher than that of the main oil exporters (See Figure 3). This means that when the oil prices are lower than $\$ 50$ per barrel, every barrel of oil extraction bears economic losses. In other words, the lack of oil resources and the high cost of oil production fundamentally limit domestic oil production and aggravate China's concerns about sufficient oil supplies.

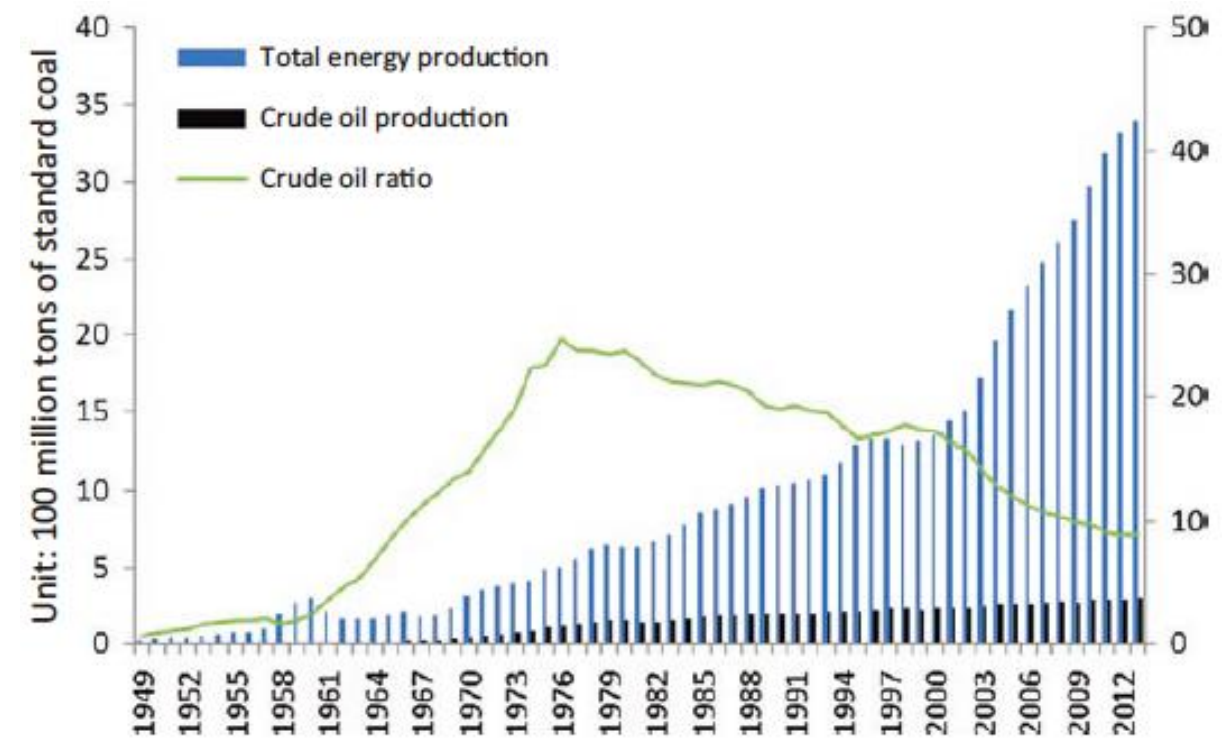

Figure 2. China's crude oil production and its share in total energy production (1949-2012)

Source: Zhu and Wang (2020), p.246 




Figure 3. The cost of producing a barrel of oil in major oil exporters

Source: Rystad Energy UCube

\subsubsection{Growing Oil Import Dependency}

China became a net oil importer in 1993, and it is the world's largest oil consumer and oil importer (IEA, 2018). China's rapid economic development over the past 30 years requires ever-increasing energy supply. As shown in Figure 4, there is a growing domestic oil supply-demand gap because the domestic oil supply has remained unchanged while the oil demand has been rising rapidly. Meanwhile, oil accounts for about 20 per cent of primary energy consumption in China (See Figure 5). In other words, China needs increasing oil imports to meet the needs of domestic socio-economic development, which ultimately results in high oil import dependency (See Figure 6). In 2020, the oil import dependency ratio in China has reached 73 per cent, higher than the 70.8 per cent in 2019, and will keep rising in the years to come (China Energy Net, 2021). Hence, it is expected that China's oil import dependency will remain at a high level, thus threatening China's oil security.

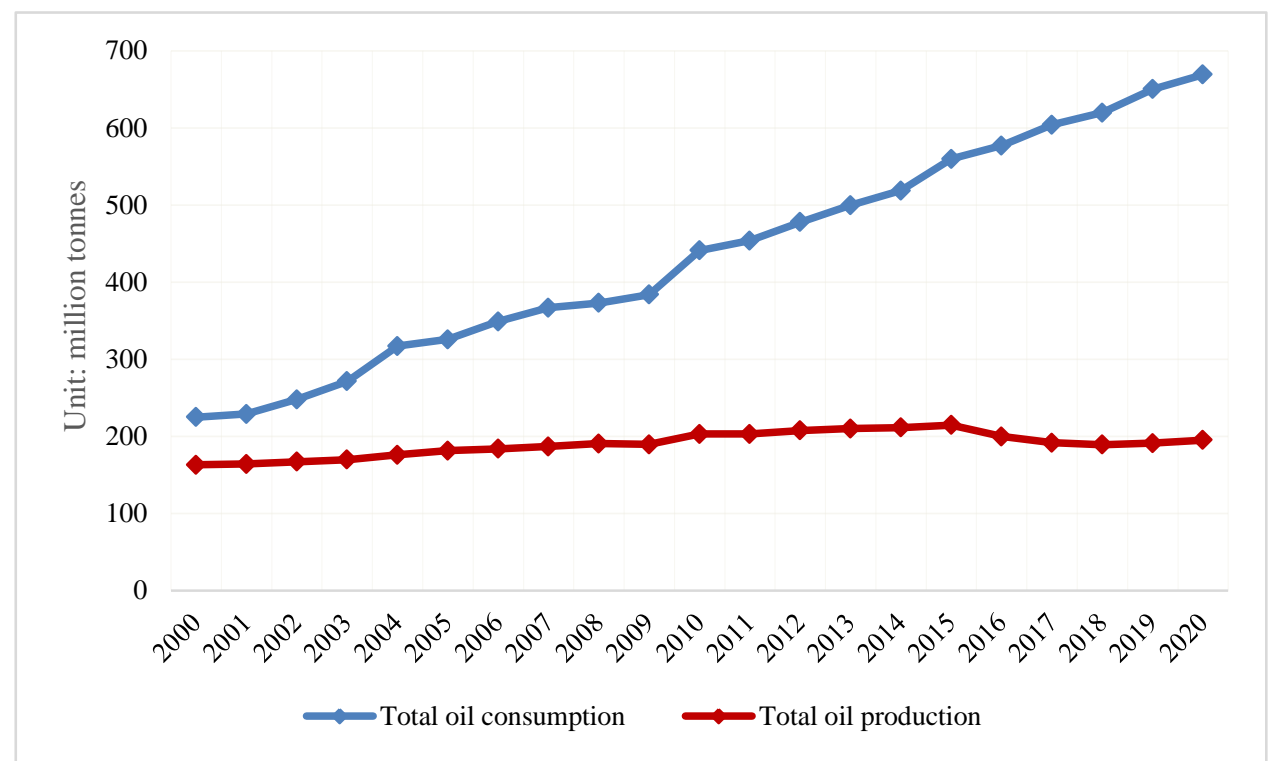

Figure 4. China's growing domestic oil supply-demand gap (2000-2020)

Source: National Bureau of Statistics (NBS) 


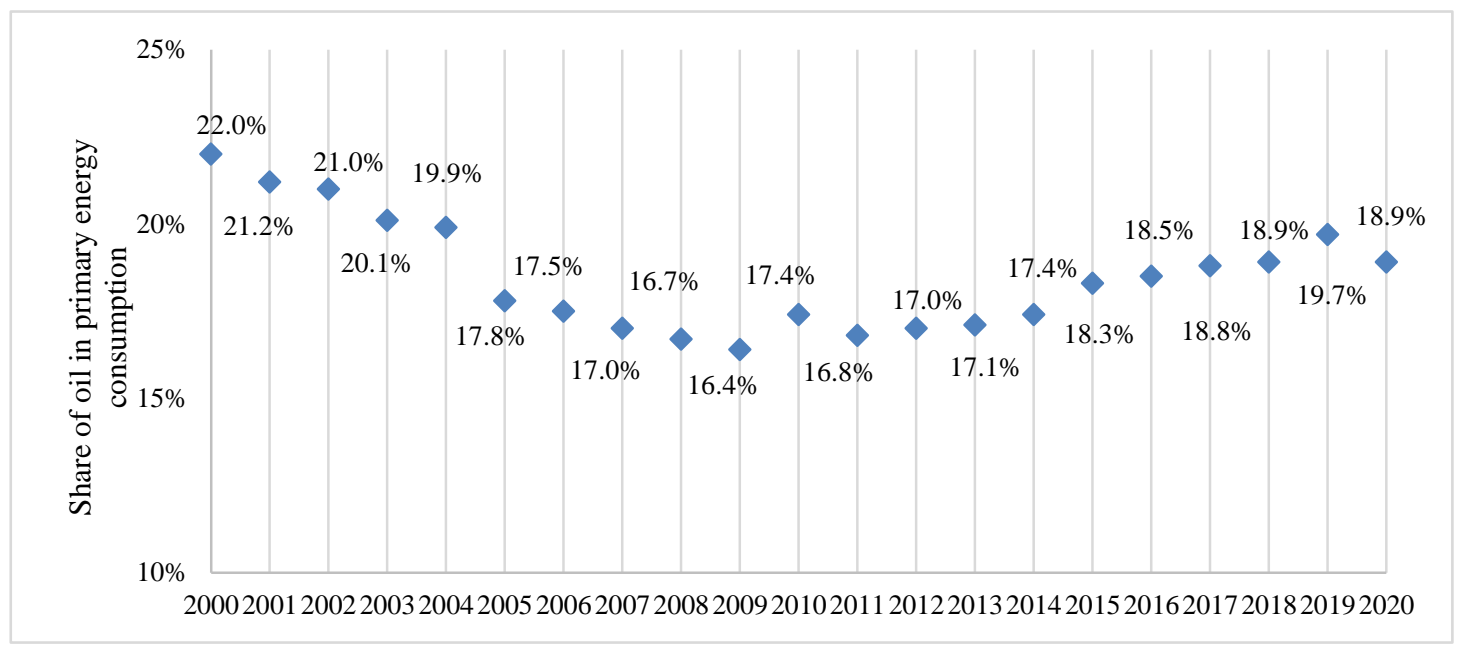

Figure 5. The share of oil in China's primary energy consumption (2000-2020)

Source: NBS

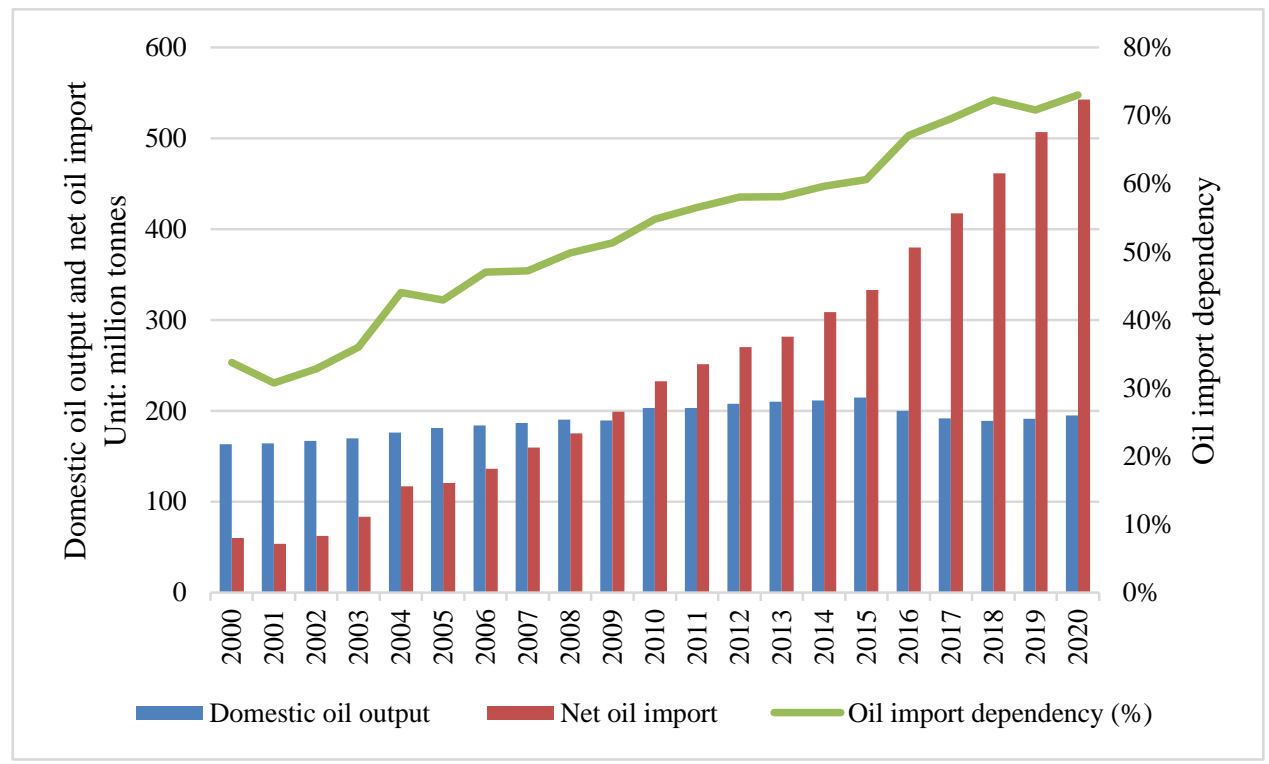

Figure 6. The oil import dependency in China (2000-2020)

Source: NBS

\subsection{Analysis of Opportunities}

\subsubsection{From "Going Out" Strategy to Belt and Road Initiative (BRI)}

The "going out" strategy was proposed as a national strategy in late 1997 and paved the way for the NOCs to expand oil exploration abroad and diversify energy supply (Xu, 2007). In the 10th Five-Year Plan (FYP), Beijing put forward that "to make full use of the resources at home and overseas and launch the 'going out' strategy of Chinese enterprises" (GOV.CN, 2000). The three NOCs take Beijing's call to "going out" and actively seek opportunities for oil $\mathrm{E} \& \mathrm{P}$ and investments overseas, aiming at improving participation in the international energy market (Wu, 2012). Consequently, the NOCs invest and trade globally, gaining energy cooperation contracts and equity oil. Specifically, the deepening bilateral or multilateral energy partnerships, going along with China's further diplomatic and economic relationship with oil-rich countries, contribute to stabilizing the NOCs' energy cooperation abroad (Wu, 2012).

The "going out" strategy was further strengthened in the 13th FYP with the implementation of the BRI. Launched in 2013, the BRI is widely regarded as a channel to expand China's openness and enhance wider and deeper cooperation worldwide (Shi \&Cai, 2020). Energy security is of great significance in the BRI. Out of a 
total of 29 oil resource-rich countries, five countries are along the Silk Road Economic Belt, and 11 countries are along the twenty-first-Century Maritime Silk Road (Liu,Chen \&Sun, 2016). Countries under BRI represent 56.7 per cent of the world total oil production and 65.2 per cent of the world total oil exports, while 80 per cent of China's crude oil is imported along with these countries and more than 50 per cent of China's overseas investment flows to BRI member countries (Pan,Wang \&Lou, 2016).

China's investment in the BRI since 2013 exceeds $\$ 819.45$ billion while energy investment accounts for above 40 per cent of the total BRI investment (Wang, 2021). (See Figure 7) In 2019, China's energy investment under BRI was $\$ 40.29$ billion, of which oil investment accounted for 18.3 per cent (Green BRI Center, 2021). Notably, it is confirmed that China's investments in the BRI did help increase oil import volume and diversify import sources, thereby ensuring China's oil security (Shi \&Cai, 2020).

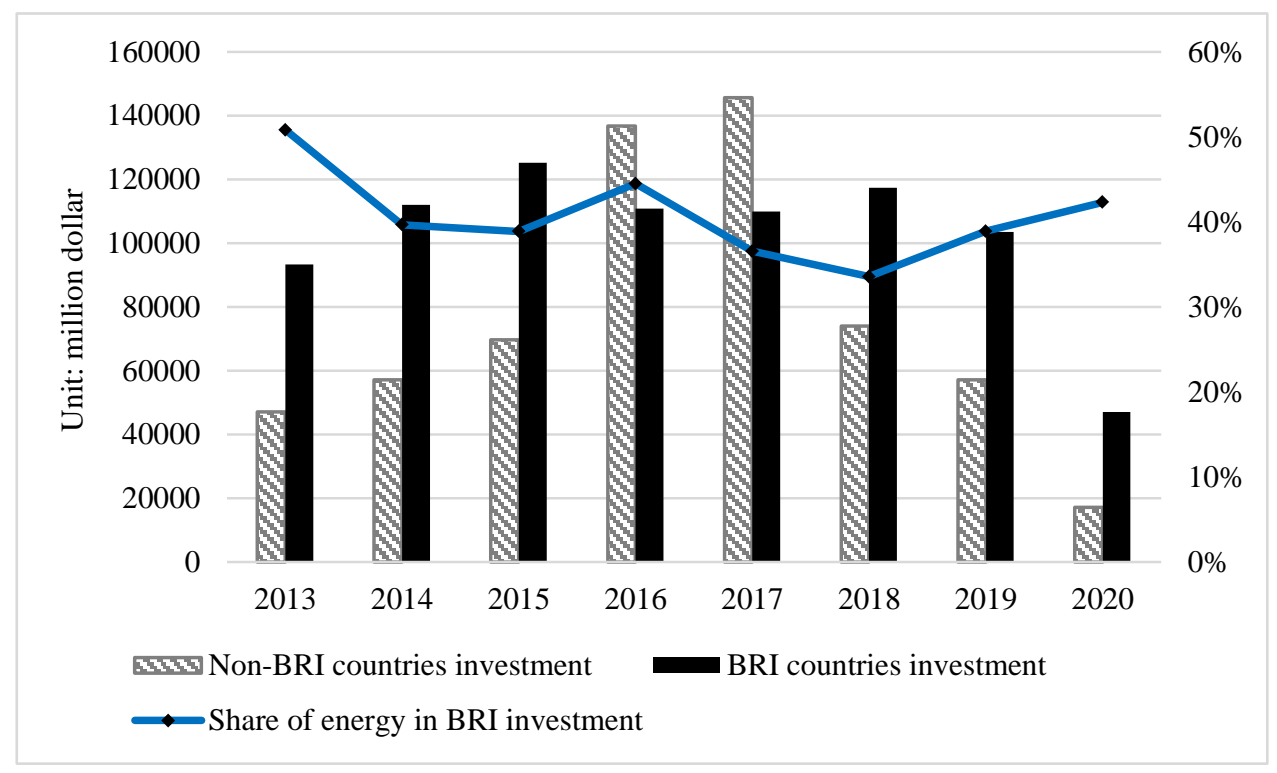

Figure 7. China's investment in BRI countries (2013-2020)

Data source: China Global Investment Tracker

\subsubsection{Reform and Opening up of the Domestic Upstream Oil Sector}

Since 2017, China has issued several updated policies to gradually open up its upstream oil and gas sector. (See Table 2) In particular, the Special Administrative Measures for the Access of Foreign Investment 2019 removed the JV Requirement (Note 2) which means that there are no restrictions on foreign investment in upstream oil and foreign investors could hold 100 per cent interest in China's upstream oil sector (Herbert Smith Freehills, 2019). On 9 January 2020, the Several Opinions on Accelerating Mineral Resources Management Reform further clarifies that foreign companies registered in China with net assets of 300 million Yuan have access to oil and gas E\&P in China and own E\&P licenses (Zhu \&Sharma, 2020). This policy, which aims to ensure China's domestic crude oil supply ultimately, comes into effect on 1 May 2020.

The opening up of the upstream oil sector breaks the NOCs' monopoly on upstream oil and encourages the non-NOCs actors to participate in China's domestic oil E \&P, which may boost domestic oil supply directly. In addition, the lifting of restrictions on domestic oil exploration and development provides an investment environment with more fairness and openness which contributes to vitalizing the market and accelerating technology innovation, and thus further improving China's oil production (Xinhua Net, 2019). As an analyst from HIS Markit puts it, a more competitive and diversified upstream sector could help alleviate China's growing energy security concerns (Al Jazeera, 2020). 
Table 2. The reforms in oil and gas sector in China

\begin{tabular}{|l|l|l|}
\hline \multicolumn{1}{|c|}{ Year } & \multicolumn{1}{|c|}{ Reforms } & \multicolumn{1}{c|}{ Expected result } \\
\hline $2015 \& 2017$ & $\begin{array}{l}\text { Xinjiang Province, as a pilot, opened the } \\
\text { conventional oil and gas blocks to Chinese } \\
\text { private investors but not foreign investors. }\end{array}$ & $\begin{array}{l}\text { Broke the market monopoly } \\
\text { of state-owned oil enterprises. }\end{array}$ \\
\hline 2017 & $\begin{array}{l}\text { Shale gas and shale oil were excluded from } \\
\text { the JV Requirement. }\end{array}$ & $\begin{array}{l}\text { International oil companies } \\
\text { could invest in China's shale } \\
\text { oil. }\end{array}$ \\
\hline 2017 & $\begin{array}{l}\text { Opinions on Deepening the Reform of the Oil } \\
\text { and Gas System }\end{array}$ & $\begin{array}{l}\text { A series of reforms in the } \\
\text { midstream and downstream } \\
\text { oil sectors. }\end{array}$ \\
\hline 2018 & $\begin{array}{l}\text { Special Administrative Measures for the } \\
\text { Access of Foreign Investment (2018) }\end{array}$ & $\begin{array}{l}\text { Foreign investors could invest } \\
\text { in Free Trade Zone. }\end{array}$ \\
\hline 2019 & $\begin{array}{l}\text { Special Administrative Measures for the } \\
\text { Access of Foreign Investment (2019) }\end{array}$ & $\begin{array}{l}\text { Remove the JV Requirement } \\
\text { and the foreign investors } \\
\text { could hold 10\% interest in } \\
\text { upstream oil and gas blocks } \\
\text { in China. }\end{array}$ \\
\hline 2020 & $\begin{array}{l}\text { Several Opinions on Accelerating Mineral } \\
\text { Resources Management Reform }\end{array}$ & $\begin{array}{l}\text { Companies registered in } \\
\text { China with net assets of 300 } \\
\text { million Yuan (around \$43 } \\
\text { million) could conduct oil and } \\
\text { gas E\&P in China and own } \\
\text { E\&P licenses. }\end{array}$ \\
\hline
\end{tabular}

\subsection{Analysis of Threats}

\subsubsection{Geopolitical Risks}

Crude oil is a strategic resource, and the uneven distribution of oil resources and the mismatch between oil demand and supply in the globe make geopolitics an important factor in oil security. Some studies believe that geopolitical risks affect oil security, and have concluded that "geopolitical risks disrupt oil supply" (Medlock, 2015) and "geopolitical risks influence international oil market and oil prices" (Bouoiyour,Selmi,Hammoudeh \&Wohar, 2019). The Middle East, Africa and Latin America have long occupied the top three regions in China's oil import, and they accounted for 44.4 per cent, 18.2 per cent and 13.3 per cent of China's total imports respectively in 2019 (BP, 2020). However, there are frequent geopolitical risks in those crude oil-rich regions, which may cause disruptions in China's oil supply.

Due to China's increasing oil demand and its lack of military force to protect overseas oil interests, geopolitical risks affects global oil markets in general and poses a greater threat to China's oil security in particular (Wang,Su \&Umar, 2021). Additionally, the dominant force of the American navy in the Strait of Malacca and the Persian Gulf further challenges China's oil security as China depends significantly on the maritime transport corridor (Xie, 2021). Finally, in terms of oil transportation, the sea lanes are vulnerable to military conflicts, piracy, terrorism and other geopolitical risks (Bouoiyour et al., 2019). Therefore, China's oil supply and its maritime oil transportation are vulnerable to geopolitical risks.

\subsubsection{Oil Price Volatility}

Affordability is also one significant factor in oil security. As China relies heavily on oil imports, high crude oil prices would destabilize China's domestic socio-economic development (Li \&Leung, 2011). However, oil price volatility causes uncertainties and has dual effects on China's oil security: on the one hand, rising oil prices stimulate oil investments at home and overseas but at the same time high oil prices raise the cost in the oil industrial chain like refining, thus producing negative effects on national oil security and destabilizing socio-economic development; on the other hand, low oil prices contribute to social and economic development but they discourage investment enthusiasm and make the oil producers lack the motivation to invest in oil development which may negatively affect oil supply in the long term (Li \&Leung, 2011; Wang et al., 2021). In 
other words, the impacts of oil prices fluctuation and high oil prices on China's oil security are complicated as they have opposite effects on socio-economic development and oil investments (Xie, 2021).

\section{Pandemic-induced SWOT Model Altered: Changes in Opportunities and Threats}

Unlike the previous oil crisis caused by international oil price fluctuations with "supply falls short of demand" and "price skyrocketing", the current "reverse oil crisis" caused by the pandemic characterized by "oversupply" and "oil price plummeting" has resulted in severe impacts on the world's political and economic development, and produced complex and far-reaching impacts worldwide. The pandemic affects the global oil market as well as China's oil supply. This part will introduce how the coronavirus affects China's oil sector and oil security from a SWOT analysis.

\subsection{The Existing Opportunities Weakened}

\subsubsection{The Opening-up of China's Upstream Slowed Down}

The year 2020 is the inaugural year of China's upstream opening-up plan which is expected to promote China's upstream oil development. However, this plan has been impaired by the pandemic and the subsequent collapse in global oil prices (Ruan, 2020). To be specific, with the global oil prices crash and oil consumption decline leading to a sharp tightening of free cash flows amid the pandemic, international oil companies and other non-NOCs are more cautious in allocating scarce capital. As most oil companies have shifted their priorities into surviving in a low oil price circumstance through a contraction strategy instead of an expansion strategy, the policies with regard to opening up upstream are unlikely to trigger a large number of new investments in China's upstream in the short term (Zhu \&Sharma, 2020).

According to IHS Markit, prior to the implementation of the upstream liberalization plan, foreign oil companies have limited available onshore opportunities in China, and their total production in China, which is no more than 3 per cent of their annual production, accounts for less than 2 per cent of China's oil production (Zhu \&Sharma, 2020). The market shares of these companies are neither attractive to China nor most of their global portfolios. Hence, China hoped to improve the market share of foreign companies in the upstream sector through the upstream liberalization plan, thereby increasing China's domestic crude oil output. Meanwhile, foreign oil companies such as BP, Shell and Total have expressed great interest in this plan and believed that the options to invest in China's upstream sector were encouraging and attractive (Herbert Smith Freehills, 2019). However, in the current environment, the pandemic-induced collapse in oil prices and oil demand decline are changing the behavior of both China's NOCs and the non-NOC upstream players that they shift their focus from developing new upstream projects to managing costs and production. The non-NOCs re-evaluate their upstream strategies and tend to be conservative in getting into new projects (Zhu \&Sharma, 2020), which is different from the previous response of the foreign companies to China's upstream opening-up policy, nor does it conform to the original intention of China's upstream reforms. In other words, the COVID-19 pandemic has made China's upstream opening-up policy less attractive, and the non-NOC players' contraction strategies are slowing down the opening up of China's upstream.

\subsubsection{Decreased Oil Investment in the BRI}

China's overseas investments in the BRI were $\$ 47$ billion in 2020, with 54 per cent less than in 2019, which were considered to be the lowest overseas investments in the BRI since 2013 possibly due to the pandemic (Wang, 2021). In particular, the energy investments in 2020 were $\$ 19.9$ billion, 50.5 per cent lower from 2019 , while the oil investments were about $\$ 2$ billion, with a 63.9 per cent decline from 2019 (China Global Investment Tracker, 2020). That is, both the energy and oil investments in the BRI fall sharply in 2020, compared to the previous year. (See Figure 8 and Figure 9) 
(Million dollars) 60000

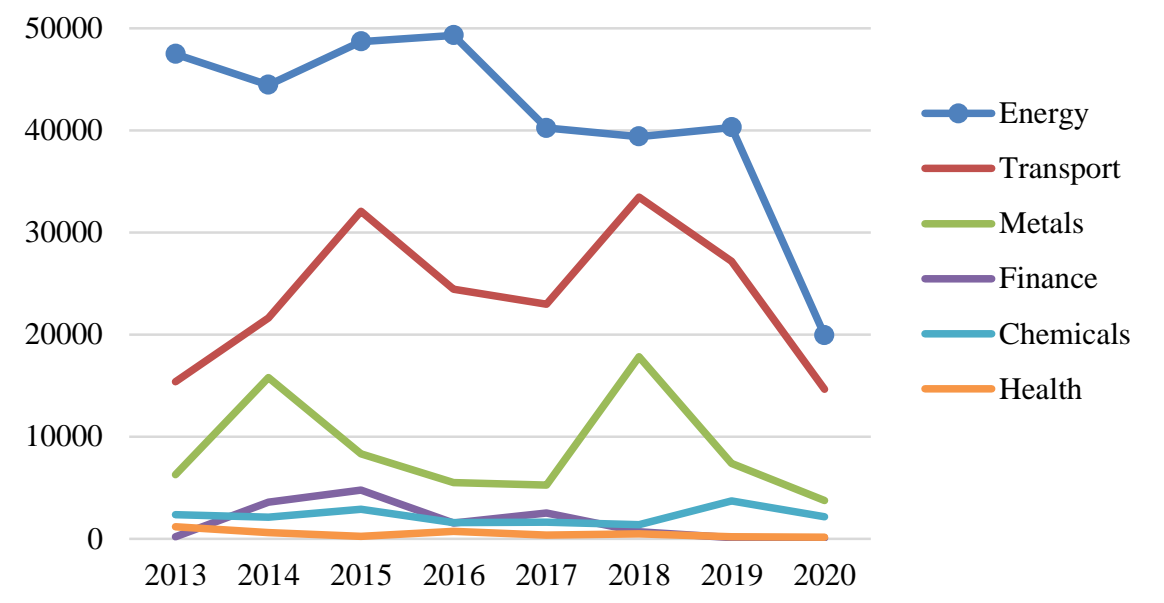

Figure 8. China's BRI investments in different sectors 2013-2020

Source: China Global Investment Tracker

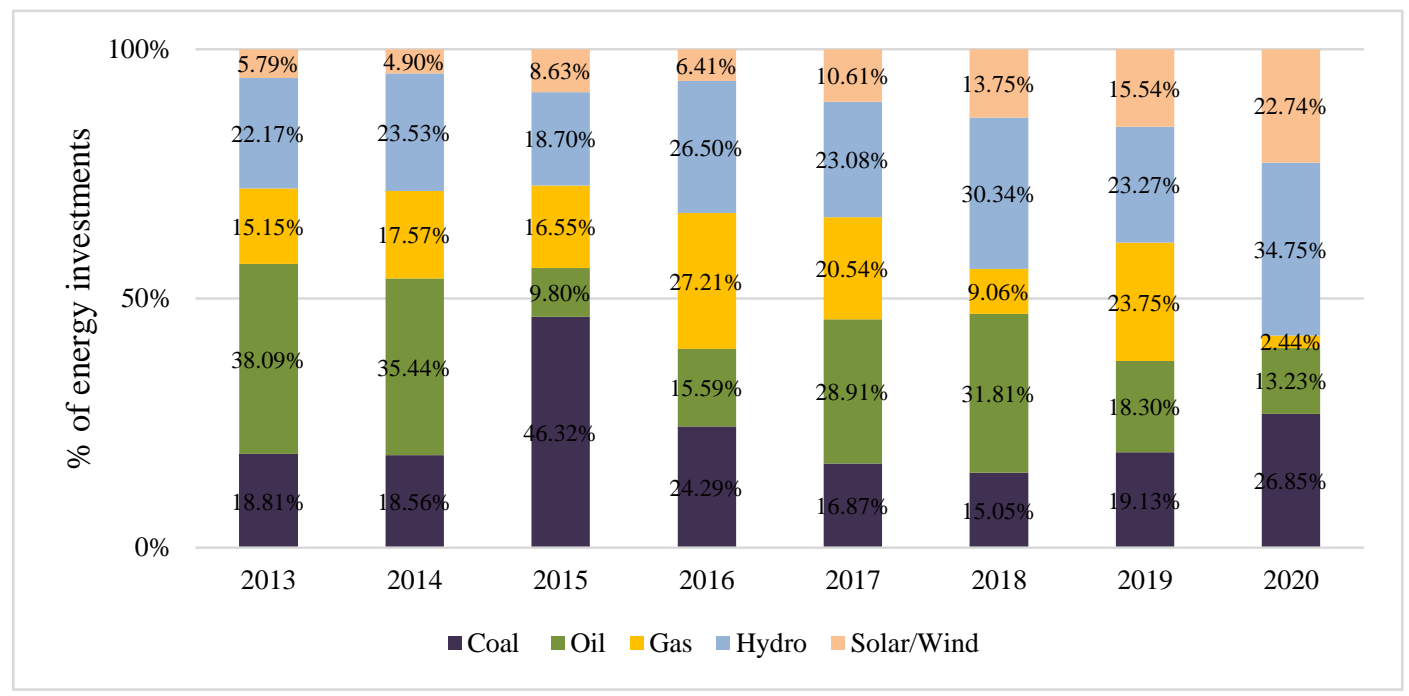

Figure 9. Sector share of Chinese energy investments in the BRI 2013-2020

\section{Source: 2021 IIGF Green BRI Center}

Specifically, Chinese oil companies' overseas oil and gas equity production was 180 million tons in 2020, with a decrease of 7.4 per cent from 2019, of which crude oil production was 143 million tons, with a decrease of 7.8 per cent from 2019 (Liu \&Jiang, 2021). (See Figure 10) In 2020, the NOCs basically stopped the development of new projects in the BRI countries and slowed down some upstream projects under construction (Liu \& Jiang, 2021). According to a report of BRI survey 2021, the primary reason for the disruption of the projects in the BRI is the social restrictions and lockdown measures, but more importantly, the pandemic-induced shift of government priority away from the BRI and local funding constraints have a greater impact on the progress of these projects (Zhang,King \&Jeffery, 2021). 


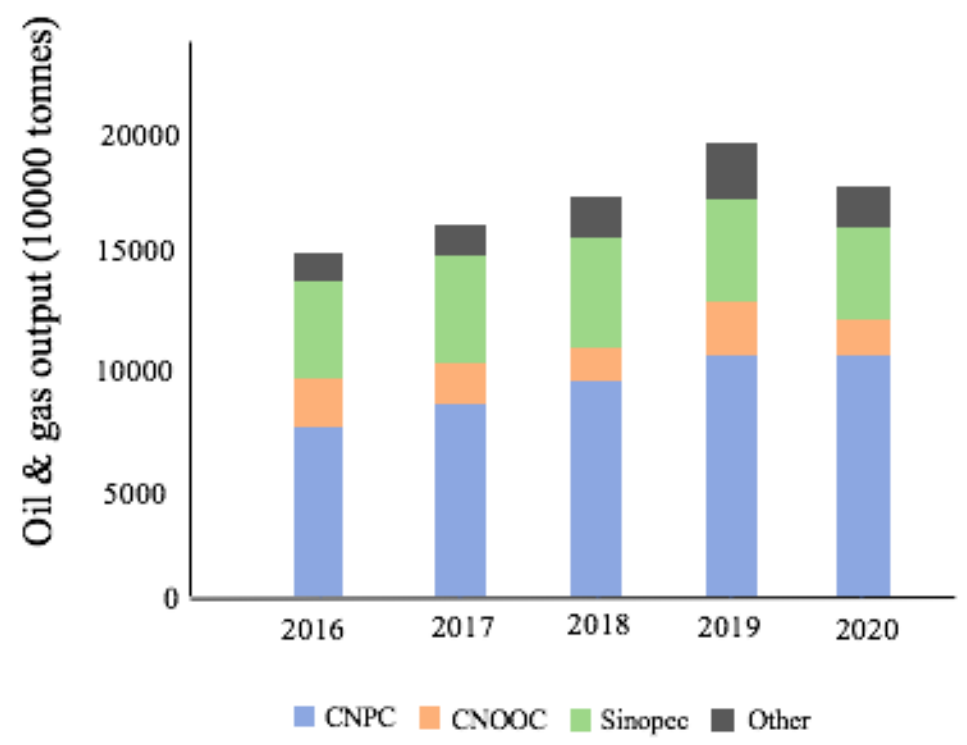

Figure 10. Chinese oil companies' overseas oil and gas equity output

Source: Liu and Jiang (2021)

Finally, funds availability exacerbates concerns about the long-term impacts of the pandemic on BRI projects as banks are cautious about whether to continue financing certain BRI projects considering the compromised profitability (Wu,Hong \&Chung, 2020). Also, it is worth thinking about whether renewables, which have become a boom in overseas investments due to the impact of the pandemic, squeeze out the share of investments that originally belong to oil. In sum, the decline of China's oil investment in the BRI brings concerns about China's oil security as it has been proved that China's oil investments in BRI countries have diversified China's source of imports and enhanced its oil security (Shi \&Cai, 2020).

\subsection{New Threats and Uncertainties Emerged}

\subsubsection{The Uncertainty over Global Oil Demand-Supply}

After plunging 9 per cent in 2020, the global oil demand is expected to rebound by $5.4 \mathrm{mb} / \mathrm{d}$ in 2021 , and by the end-2022, it should return to its pre-pandemic level(IEA, 2021). However, the recovery is uneven not only across sectors and products but amongst regions (IEA, 2021). For example, the jet demand will be the slowest to recover as the aviation sector has been seriously affected by travel restrictions. Gasoline demand is also predicted to recover slowly due to the pandemic-induced change of working methods like teleworking from home. Diesel and petrochemical will be boosted by the robust demand for economic recovery. Figure 11 shows the demand recovery of different oil products in OECD countries. Meanwhile, considering the vaccination, each country has a different vaccination rate and thus a different pace of recovery, which results in a non-synchronous recovery of oil demand worldwide. 


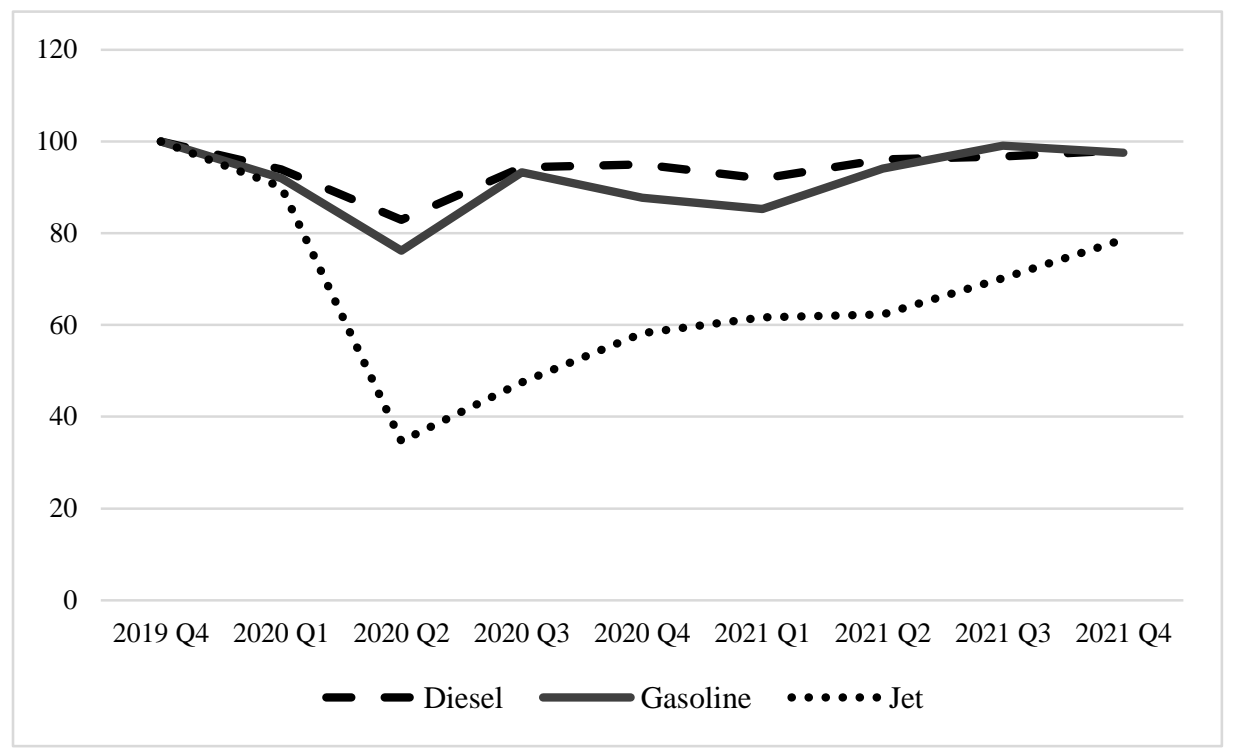

Figure 11. Oil demand in OECD countries by product (Index, 2019 Q4=100)

Source: World Bank

On the supply side, it is calculated that the pandemic has halved the growth in non-OPEC oil supply, while the OPEC and Russia agreed to cut the overall oil production by $9.7 \mathrm{mb} / \mathrm{d}$ in 2020 , aiming at stabilizing international oil prices (IEA, 2020b). In 2021, oil production from non-OPEC is set to rise $710 \mathrm{~kb} / \mathrm{d}$, while the oil supply from OPEC could increase by $800 \mathrm{~kb} / \mathrm{d}$ (IEA, 2021). In the medium and long term, the possibility of a serious shortage of world oil supply is relatively small.

The demand is indeed the leading cause of and the ultimate solution to the present dilemma in the global oil market caused by the pandemic. Although there is a pick-up in international oil prices and oil demand in 2021, the balance of supply and demand is still fragile as the pandemic has not ended and the economy has not fully recovered. As the world's top oil importer, China's foreign oil dependency rate reaches 70.8 per cent in 2019 , which means China is highly sensitive to a global oil market with uncertainty. Regardless of whether the crude oil is an oversupply or in short supply in the global oil market, oil supply-demand imbalance and the accompanying price fluctuations will bring fluctuations to China's oil supply.

\subsubsection{Decrease in Global Upstream Investments}

The pandemic-induced economic recession and low oil prices hit the energy industry severely and the global upstream investment dropped by 30 per cent in 2020 which was the lowest in the past ten years (Liu \&Jiang, 2021). Global oil and gas exploration and production are in a downturn. The global investment in oil and gas upstream in 2020 was $\$ 328$ billion, with almost a one-third ( $\$ 155$ billion) down from 2019 (IEA, 2020a). (See Figure 12) Specifically, after the oil price plummeted in 2020, the international oil companies including Exxon, BP, Shell, Chevron, Total, cut their investment plans for the next five years by 30 per cent, and reduced their spending on upstream operations by 40 per cent, resulting in oil output decline accordingly in the following years (Li, 2021a). (See Figure 13) That is, the pandemic-induced plunge in oil prices and production cuts have led to a significant reduction in cash flow of upstream investments, which, along with the reduced oil demand and energy transition stimulated by the pandemic, will affect the future oil and gas production capacity and ultimately affect global oil supply and oil prices. 


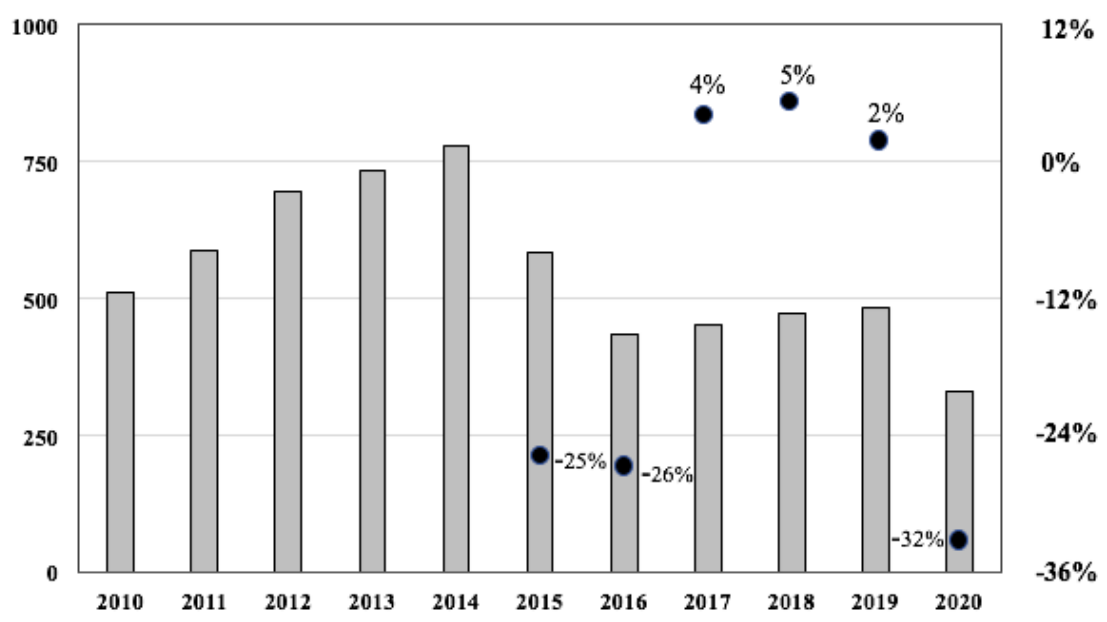

Figure 12. Global investments in oil and gas upstream (billion dollar) and percentage change from previous year Source: IEA

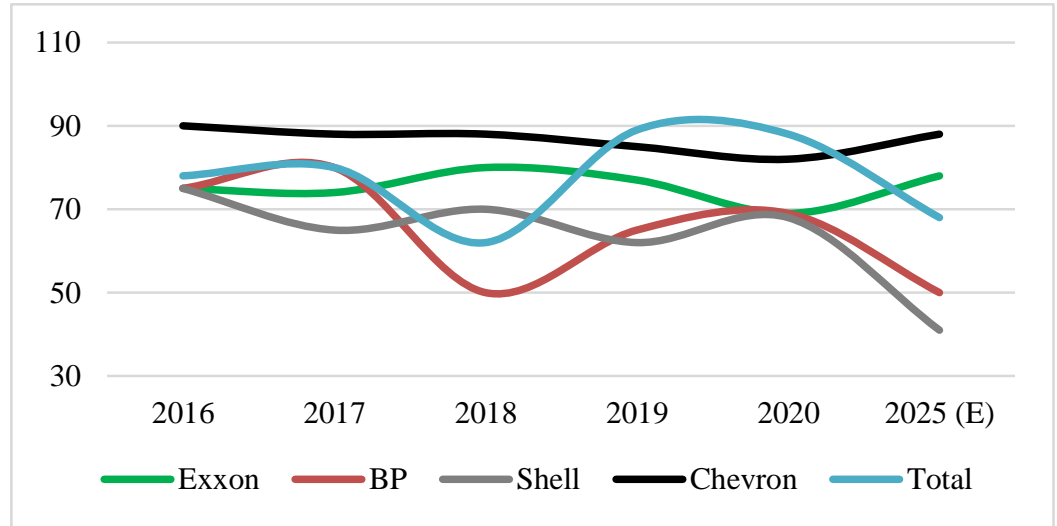

Figure 13. The share of upstream investment in international oil companies

Source: Li (2021a)

\subsection{Rising Opportunities for Ensuring Oil Security}

\subsubsection{Improving China's Strategic Petroleum Reserve (SPR)}

SPR is considered to be an effective means to deal with the oil crises and reduce the impacts of oil supply interruption. For example, the member states of the IEA are required to store at least 90 days of net imports. In China, the original preparations for national SPR began in the 1990s, and the construction of the first four SPR sites which could hold about 103 million barrels oil, commenced in 2004 (Singh, 2012). As of mid-2017, China has built nine national oil reserve bases with about 275 million barrels (37.73 million tons) of SPR (See Table 3), equivalent to around 33 days of net imports or 23 days of total consumption.

Table 3. China's SPR based on government announcements

\begin{tabular}{|l|l|}
\hline Date & SPR stockpiling (million barrels) \\
\hline Nov-2014 & 91 \\
\hline June-2016 & 243 \\
\hline June-2017 & 275 \\
\hline *end-2020 & $290-370$ \\
\hline
\end{tabular}

\section{*: estimates by analysts}

Source: Chen and Xu (2020) 
Major crude oil importers such as China have been known to build their strategic reserves when prices are low (Wood Mackenzie, 2020). China took advantage of the plunge in oil prices to reserve cheap oil and increase its SPR in the first quarter of 2020, with its crude oil imports rising 5 per cent to 127.19 million tons (Zhang \& $\mathrm{Li}$, 2020). By the end-September 2020, China held about 1.16 billion barrels of crude including government SPR and commercial inventories (Figure 14 shows the share of SPR and commercial reserves in total oil reserves), equivalent to about 105 days of net imports, and it is estimated that the SPR would reach 290 million to 370 million barrels by end-2020 (Chen $\&$ Xu, 2020). As a result, according to the data from the General Administration of Customs, China's crude oil imports in 2020 reached a record of 542 million tons, a year-on-year increase of 7.3 per cent, while the cost of crude oil imports was 1.22 trillion yuan, a year-on-year decrease of 26.8 per cent. China gets more crude oil with less money and simultaneously increases its SPR amid the COVID-19 period.

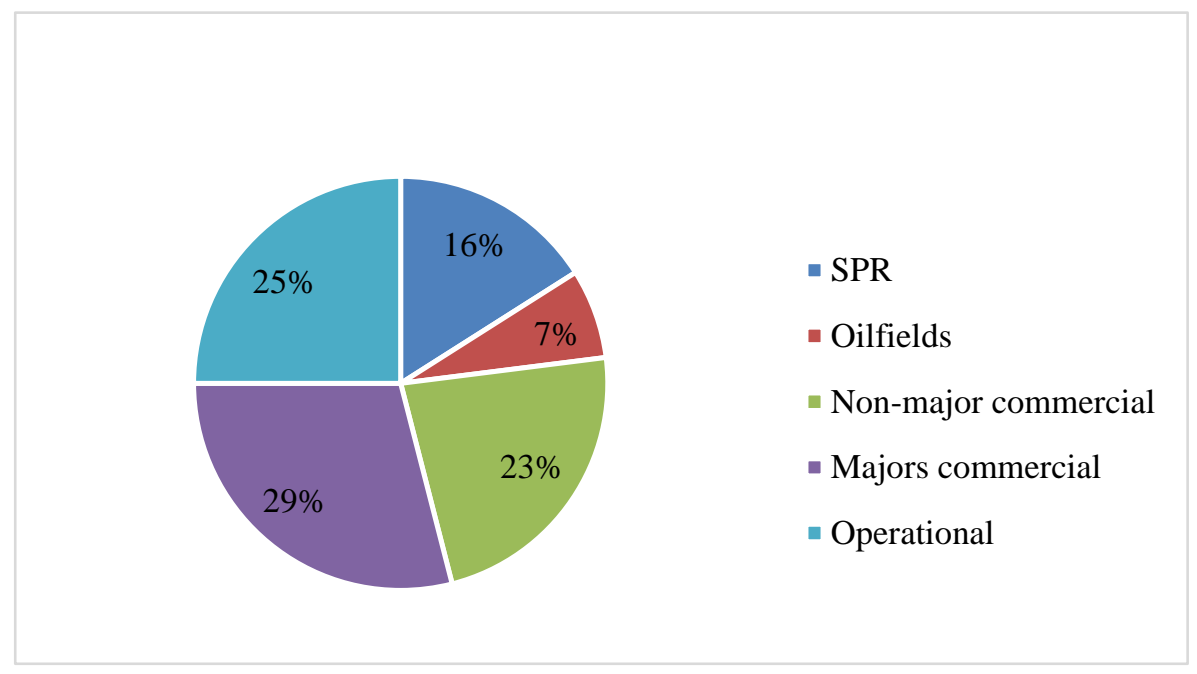

Figure 14. China's crude oil reserves mix in 2020

Source: Sublime China Information 2020

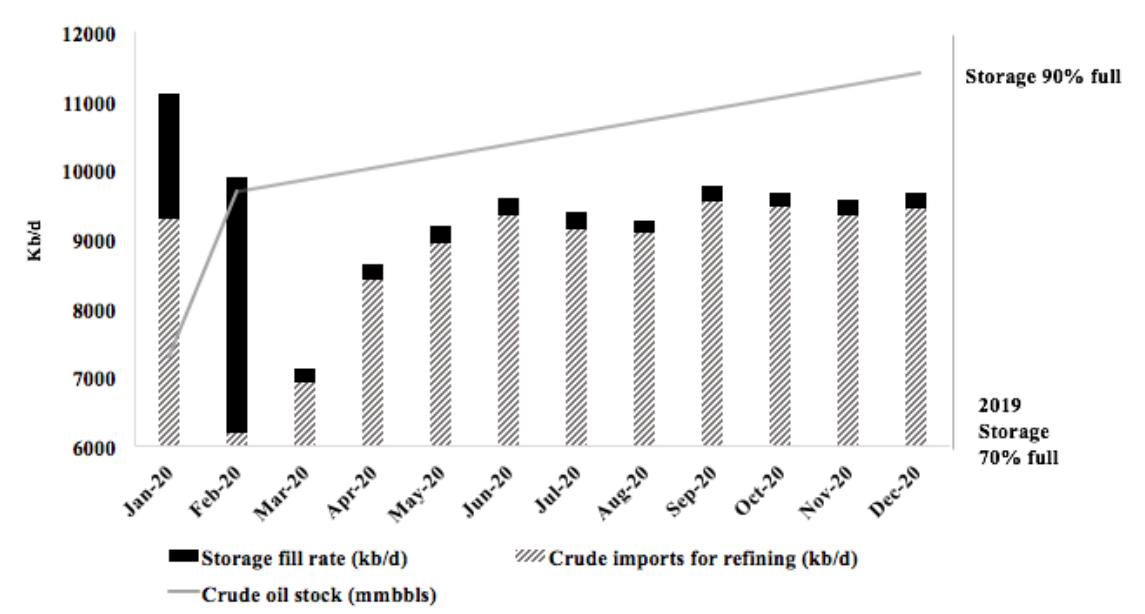

Figure 15. China's crude oil import balance 2020

Source: NBS, and Wood Mackenzie

Although there is no official publicly released data on China's total oil reserve capacity, it is speculated that China's oil reserve, including government SPR and commercial oil reserves, would reach 1.15 billion barrels in 2020, equivalent to around 83 days of its domestic oil demand (Wood Mackenzie, 2020). Compared with the 900 million barrels oil reserves in 2019, which is equivalent to China's oil demand for about 70 days and 70 per cent of its 2019 total reserve capacity, the 1.15 billion barrels in 2020 hits 90 per cent of China's total storage capacity (Wood Mackenzie, 2020). (See Figure 15) Meanwhile, an analyst from Energy Aspects estimated that China's 
emergency oil reserves, including commercial reserves, exceeded 100 days of net oil imports in the third quarter of 2020, while Bloomberg estimated that China's oil inventories rose to 1.09 billion barrels in 2020 (Bloomberg, 2021). In other words, data from several sources reflect that China's oil reserves, including the SPR, have greatly increased due to the pandemic.

\subsubsection{Rising Green Opportunities Stimulated by the Pandemic}

Low oil prices present a window of opportunity to implement structural reforms in the energy market (Baffes,Kose,Ohnsorge \&Stocker, 2015). The impact of the coronavirus on the energy market is one of the significant factors that prioritize low-carbon development and climate change action in national policies, and the climate change issues have moved from the periphery of international relations and geopolitics to the center stage (Froggatt \&Quiggin, 2021). As a result, "green recovery" has been launched by the major powers as the priority choice to deal with the economic recession caused by the pandemic. In 2020, global low-carbon investment rose by 9 per cent to $\$ 501.3$ billion in 2020, up from $\$ 458.6$ billion in 2019 and $\$ 235.4$ billion in 2010, while the total investment for Europe, China and the U.S. were $\$ 166.2$ billion -67 per cent higher than 2019, $\$ 134.8$ billion and $\$ 85.3$ billion respectively (BNEF, 2021). Notably, China's low-carbon investment was the largest in the world in 2020. Following President Xi's commitment to carbon neutrality by 2060 at the UN General Assembly in 2020, low-carbon transition has been re-emphasized in a series of conferences involving national economic development and economic recovery-oriented cooperation to fight the pandemic (See Table 4).

Table 4. Examples of President Xi Jinping's speech on low-carbon development

\begin{tabular}{|c|c|c|}
\hline Date & Meeting & Content \\
\hline Sept.22, 2020 & UN General Assembly & Carbon peak by 2030 and carbon neutrality by 2060 . \\
\hline Dec. 12,2020 & Climate Ambition Summit & $\begin{array}{l}\text { By } 2030 \text {, carbon emission per unit of GDP declines } \\
60 \%-65 \% \text { compared with } 2005 \text {; } \\
\text { Non-fossil fuel in the energy mix reaches about } 25 \% \text {; } \\
\text { The total installed capacity of wind and solar power } \\
\text { generation reaches more than } 1.2 \text { billion kilowatts. }\end{array}$ \\
\hline Dec. $16-18,2020$ & $\begin{array}{l}\text { Central Economic Work } \\
\text { Conference }\end{array}$ & $\begin{array}{l}\text { To promptly formulate the action plan for peaking } \\
\text { carbon emissions by } 2030 \text {; } \\
\text { To build a national carbon emissions trading market. }\end{array}$ \\
\hline Feb.19, 2021 & $\begin{array}{l}\text { The } 18 \text { th Meeting of the } \\
\text { Central Committee for } \\
\text { Comprehensively } \\
\text { Deepening Reform }\end{array}$ & $\begin{array}{l}\text { To establish an economic system for green and low- } \\
\text { carbon circular development. }\end{array}$ \\
\hline Mar. 15, 2021 & $\begin{array}{l}\text { The Ninth Meeting of the } \\
\text { Central Committee for } \\
\text { Financial and Economic } \\
\text { Affairs }\end{array}$ & $\begin{array}{l}\text { To build a clean, low-carbon, safe and efficient } \\
\text { energy system; } \\
\text { To build a new power system with renewable energy } \\
\text { as the main body. }\end{array}$ \\
\hline July 16,2021 & $\begin{array}{l}\text { The Informal Economic } \\
\text { Leaders' Retreat of the Asia- } \\
\text { Pacific Economic } \\
\text { Cooperation (APEC) }\end{array}$ & $\begin{array}{l}\text { China supports APEC in advancing cooperation on } \\
\text { sustainable development, and making energy more } \\
\text { efficient, clean and diverse. }\end{array}$ \\
\hline
\end{tabular}

In addition, oil companies are turning to invest in renewable energy to reduce the pandemic-induced losses and gain greater returns. For example, BP and Shell deepened their commitment to low-carbon development and cut their oil assets by $\$ 15-20$ billion as they believed that energy transition was a new development strategy (Ambrose, 2020). In China, the NOCs also began to dabble in renewable energy to reduce losses and echo the aforementioned national development strategy of low-carbon transition and carbon neutrality. The CNPC strives to promote gas development and try to build oil-hydrogen stations; the Sinopec plans to develop a full hydrogen industry chain, accelerate the technological innovation of renewable energy and the development of 
decarbonization technologies; the CNOOC is committed to developing an energy development model of "green oil fields" that combines offshore wind and solar power and offshore oil fields (Li, 2021b).

A series of literature has studied the relationship between renewable energy development and energy security (Johansson, 2013; Cox,Beshilas \&Hotchkiss, 2019). For example, Paravantis and Kontoulis (2020) analyzed the role of renewable energy in shaping energy security against global geopolitical threats and other uncertainties. Drawing on insights from the existing researches concerning renewable energy development and energy security, this research believes that the rising green opportunities in the COVID-19 pandemic affect oil security positively in the following ways: Firstly, rising green opportunities drive the innovation and popularization of clean technologies, contributing to the sustainable supply of clean oil and gas. For instance, technology innovation promotes the exploitation of unconventional oil and gas resources such as shale oil that has been restricted due to previous technology, and thus improving the unconventional oil supply. Secondly, the development of renewables promotes oil and gas production through the shared infrastructure. The renewables such as offshore wind, have the overlapping infrastructure with offshore oil and gas development. According to the IEA, around 40 per cent of an offshore wind project's full lifetime costs, including construction and maintenance, have synergies with the offshore oil and gas sector (IEA, 2019b), which encourages the oil companies to invest in integrated offshore 'oil and gas plus wind' projects. Lastly, the rising green opportunities alter the way energy and geopolitics interact, and thus alleviate the oil importers' concerns about the political instability in the Middle East. The replacement of fossil energy by renewable energy contributes to, on the one hand, tackling climate change, and on the other hand, alleviating concerns about energy security as the diverse alternative renewable energy supplies away from the oil-producing regions help to get rid of the shackles of geopolitics (Wang, 2020). Furthermore, as the renewables are domestically controllable energy supplies, they are believed the most effective way to reduce energy import dependency and supply threats (Bang, 2010).

It should be noted that the low-carbon transitions begin much earlier than the outbreak of the pandemic, and China launched its energy revolution in 2014. However, the pandemic has accelerated the structural changes of the energy system and green stimulus has become more urgent for economic recovery worldwide. As the pandemic has fundamentally changed the consumption patterns, and forced oil companies to invest in clean technologies for greater returns, it is expected that energy transition will be accelerated and oil demand will peak earlier than previously estimated (Rystad Energy, 2020).

\section{Conclusion}

In this research, the SWOT analytical model is used to review the strengths and weaknesses of China's oil sector, as well as the opportunities and threats it faces that affect China's oil security. However, the pandemic has changed the SWOT model: the existing opportunities such as oil investments in the BRI and domestic upstream opening-up have been weakened; new threats including the uncertainty over global oil demand-supply and decrease in global upstream investments have emerged; opportunities involving an increase in domestic SPR and low-carbon development are rising amid the pandemic. Notably, the challenges posed by the COVID-19 pandemic to China's oil security have not jumped out of the traditional oil security framework, that is, it is still oil supply and price issues related to geopolitics, inter-state relations and market mechanisms. The difference is that, as a pandemic, the spread and duration of the coronavirus and its impact on global economic development bring uncertainties to China's oil supply as well as the global oil market.

China has always attached great importance to its oil security. Even if the COVID-19 pandemic has caused low oil prices and oil oversupply in the global oil market, China still has not relaxed its guard against national oil security. Faced with the impact of the pandemic on the global oil market, Beijing is in charge of unified deployment and command at the strategic level, including setting domestic oil E\&P targets, increasing national SPR and ambitiously promote low-carbon development. The three NOCs are stabilizers of China's domestic oil market as they endeavor to fulfil the domestic crude oil output targets, reduce oil capital expenditure and operation costs, and respond to Beijing's call to advance the energy transition.

It's worth noting that the green opportunities have risen amid the pandemic which are welcomed by the major countries as a way to achieve economic recovery and accepted by the oil companies as a means to reduce losses caused by the pandemic. Also, the green opportunities are providing growth momentum to low-carbon technologies and changing the structure of the energy market both in China and the world. The COVID-19 pandemic has demonstrated the vulnerability of the global energy market to systemic risks and accelerated the transition to renewable energy. Going forward, the globe's twin foci on economic recovery from the pandemic and low-carbon transition to combat climate change could weaken the outlook for oil demand and construct a resilient energy system. 


\section{References}

Al Jazeera. (2020, January 09). Foreign firms can finally tap into China's oil and gas industry. Retrieved June 29, 2021, from https://www.aljazeera.com/economy/2020/1/9/foreign-firms-can-finally-tap-into-chinas-oil-and-gas-industr y

Ambrose, J. (2020, May 17). BP chief says Covid has deepened commitment to net-zero emissions. The Guardian. Retrieved July 10, 2021, from

https://www.theguardian.com/business/2020/may/17/bp-chief-says-covid-has-deepened-commitment-to-net -zero-emissions

Andrews-Speed, P., \& Dannreuther, R. (2013). China, oil and global politics. Oxford: Routledge. 85-89. https://doi.org/10.1080/01495933.2013.754169

Baffes, J., Kose, M. A., Ohnsorge, F., \& Stocker, M. (2015). The great plunge in oil prices: causes, consequences, and policy responses. World Bank Group, Policy Research Note, Nr. 94725. https://doi.org/10.2139/ssrn.2624398

Bang, G. (2010). Energy security and climate change concerns: Triggers for energy policy change in the United States? Energy Policy, 38, 1645-53. https://doi.org/10.1016/j.enpol.2009.01.045

Bloomberg. (2021, February 26). China's oil reserves are close to reaching storage capacity. Retrieved July 03, 2021, from

https://www.hindustantimes.com/world-news/chinas-oil-reserves-are-close-to-reaching-storage-capacity-10 1614331454375.html

BNEF. (2021, January 19). Energy transition investment trends_Tracking global investment in the low-carbon energy transition. Retrieved from

https://assets.bbhub.io/professional/sites/24/Energy-Transition-Investment-Trends_Free-Summary_Jan2021 .pdf

Bouoiyour, J., Selmi, R., Hammoudeh, S., \& Wohar, M. E. (2019). What are the categories of geopolitical risks that could drive oil prices higher? Acts or threats? Energy Economics, 84, 104523. https://doi.org/10.1016/j.eneco.2019.104523

BP. (2020, June). Statistical review of world energy. Retrieved February 02, 2021, from https://www.bp.com/en/global/corporate/energy-economics/statistical-review-of-world-energy.html

BP. (2021, June). Statistical review of world energy. Retrieved July 11, 2021, from https://www.bp.com/content/dam/bp/business-sites/en/global/corporate/pdfs/energy-economics/statistical-re view/bp-stats-review-2021-full-report.pdf

Chen, A., \& Xu, M. (2020, November 18). China's top independent crude oil storage operators, SPR updates. Reuters. Retrieved July 05, 2021, from https://www.reuters.com/article/china-oil-storage-idUSL4N2HS1CV

China Energy Net. (2021, February 26). China's foreign oil dependence soars to 73\%. Retrieved March 15, 2021, from https://www.china5e.com/news/news-1110148-1.html

China Global Investment Tracker. (2020, September 15). China's investment under Belt and Road Initiative. American Enterprise Institute \& Heritage Foundation. Retrieved October 10, 2020, from https://www.aei.org/china-global-investment-tracker/

Cornish, L. (2021, June 23). Interactive: Who's funding the COVID-19 response and what are the priorities? Retrieved June 23, 2021, from

https://www.devex.com/news/interactive-who-s-funding-the-covid-19-response-and-what-are-the-priorities96833

Cox, S., Beshilas, L., \& Hotchkiss, E. (2019, October). Renewable energy to support energy security. https://doi.org/10.2172/1569691

Deng, Y. (2020). Why are the three NOCs still losing money. China Economic Weekly, 9. Retrieved November 20, 2020, from http://paper.people.com.cn/zgjjzk/html/2020-05/15/content_1987813.htm

Dess, G. (2018). Strategic management: creating competitive advantages. McGraw-Hill Higher Education. 73.

Erickson, A. S., \& Collins, G. B. (2010). China's oil security pipe dream: The reality, and strategic consequences 
of seaborne imports. Naval War College Review, 63, 88-112.

Froggatt, A., \& Quiggin, D. (2021, March 29). China, EU and US cooperation on climate and energy. Retrieved June 20, 2021, from

https://www.chathamhouse.org/2021/03/china-eu-and-us-cooperation-climate-and-energy/02-impacts-covid -19-energy-and-climate

GOV.CN. (2000, October 11). Proposal of the central committee of the Communist Party of China on formulating the tenth Five-Year Plan for national economic and social development. Retrieved June 20, 2021, from http://www.gov.cn/gongbao/content/2000/content_60538.htm

Green BRI Center. (2021, January 21). China Belt and Road Initiative investment report summary 2020. Retrieved June 25, 2021, from https://green-bri.org/china-belt-and-road-initiative-bri-investment-report-2020/

Guo, F., Huang, C., \& Wu, X. (2019). Strategic analysis on the construction of new energy corridor ChinaPakistan-Iran-Turkey. Energy Reports, 5, 828-41. https://doi.org/10.1016/j.egyr.2019.06.007

Herbert Smith Freehills. (2019, July 30). China removes restrictions on foreign investment in upstream oil and gas. Retrieved June 29, 2021, from https://www.lexology.com/library/detail.aspx?g=0e244d8f-4124-435e-8af7-74cfbe4de554

IEA. (2020a, May). World energy investment 2020. IEA, Paris. Retrieved from https://www.iea.org/reports/world-energy-investment-2020

IEA. (2018, November). Retrieved January 17, 2021, from https://www.iea.org/reports/world-energy-outlook-2018

IEA. (2019a, December 02). Energy security: Reliable, affordable access to all fuels and energy sources. Retrieved October 10, 2020, from https://www.iea.org/areas-of-work/ensuring-energy-security

IEA. (2019b, November ). Offshore wind outlook 2019. Retrieved June 20, 2021, from https://www.iea.org/reports/offshore-wind-outlook-2019

IEA. (2020b, March 09). Oil 2020. Retrieved June 15, 2020, from https://www.iea.org/reports/oil-2020

IEA. (2021, June). Oil makert report. Retrieved June 30, 2021, from https://www.iea.org/reports/oil-market-report-june-2021

IEA. (2020c, October 13). World energy outlook 2020. Retrieved October 15, 2020, from https://www.iea.org/reports/world-energy-outlook-2020

Irfan, M., Hao, Y., Panjwani, M. K., Khan, D., Chandio, A. A., \& Li, H. (2020). Competitive assessment of South Asia's wind power industry: SWOT analysis and value chain combined model. Energy Strategy Reviews, 32, 100540. https://doi.org/10.1016/j.esr.2020.100540

Jaber, J., Elkarmi, F., Alasis, E., \& Kostas, A. (2015). Employment of renewable energy in Jordan: Current status, SWOT and problem analysis. Renewable and sustainable energy reviews, 49, 490-99. https://doi.org/10.1016/j.rser.2015.04.050

Johansson, B. (2013). Security aspects of future renewable energy systems-A short overview. Energy, 61, 598-605. https://doi.org/10.1016/j.energy.2013.09.023

Kong, B. (2010). China's international petroleum policy. Santa Barbara, CA: Praeger Security International.

Kong, B. (2019). Modernization through globalization: Why China finances foreign energy projects worldwide. Singapore: Palgrave Pivot. https://doi.org/10.1007/978-981-13-6016-9

Kong, B., \& Gallagher, K. P. (2017). Globalizing Chinese energy finance: The role of policy banks. Journal of Contemporary China, 26(108), 834-51. https://doi.org/10.1080/10670564.2017.1337307

Li, C. (2021a, April 23). The strategic choice of oil companies. Retrieved June 18, 2021, from https://mp.weixin.qq.com/s/CssSbNgrFjpEdvy0ZXMHuA

Li, R., \& Leung, G. C. (2011). The integration of China into the world crude oil market since 1998. Energy Policy, 39, 5159-66. https://doi.org/10.1016/j.enpol.2011.05.048

Li, Y. (2021b). The NOCs' carbon neutrality action plan (in Chinese). China City Energy Development Industrial Alliance. Retrieved from http://www.ccedia.com/news/1515.html

Liu, C., Chen, J., \& Sun, X. (2016). Location selection of China's oil import portfolio under the Belt and Road 
Initiative. Energy of China , 3, 19-24.

Liu, C., \& Jiang, X. (2021).Domestic and international oil and gas industry development report 2020 (In Chinese). CNPC Economics \& Technology Research Institute (ETRI). Beijing: Petroleum Industry Press.

Markovska, N., Taseska, V., \& Pop-Jordanov, J. (2009). SWOT analyses of the national energy sector for sustainable energy development. Energy, 34, 752-56. https://doi.org/10.1016/j.energy.2009.02.006

Medlock, K. B. (2015). To lift or not to lift? The US crude oil export ban: Implications for price and energy security. James A. Baker III Institute for Public Policy of Rice University. Retrieved from http://bakerinstitute.org/research/lift-or-not-lift-us-crude-oil-export-ban-implications-price-and-energy-secu rity/

OPEC. (2020, June 06). Brief high-level remarks by OPEC secretary general. Retrieved June 17, 2021, from https://www.opec.org/opec_web/en/press_room/5974.htm

Pan, J., Wang, L., \& Lou, Y. (2016). Oil and gas resource potentials and strategic selection under the Belt and Road Initiative. International Petroleum Economics, 10, 13-16.

Paravantis, J. A., \& Kontoulis, N. (2020). Energy security and renewable energy: A geopolitical perspective. In Mansour Al Qubeissi et al. (Ed.), Renewable energy-resources, challenges and applications. IntechOpen. https://doi.org/10.5772/intechopen.91848

Patey, L. (2014).The new kings of crude: China, India, and the global struggle for oil in Sudan and South Sudan. London: Hurst \& Company. 82-84.

Ruan, Z. (2020). The Chinese majors' responses to the collapse in global oil prices and the COVID-19 pandemic: An upstream perspective. The Oxford Institute for Energy Studies, Energy Insight, 78.

Rystad Energy. (2020, November 02). Covid-19 and energy transition will expedite peak oil demand to 2028 and cut level to 102 million bpd. Retrieved July 10, 2021, from

https:/www.rystadenergy.com/newsevents/news/press-releases/covid-19-and-energy-transition-will-expedit e-peak-oil-demand-to-2028-and-cut-level-to-102-million-bpd/

Shi, B., \& Cai, T. (2020). Has China's oil investment in Belt and Road Initiative countries helped its oil import? Energies, 13, 3176. https://doi.org/10.3390/en13123176

Shirody, M. (2016). SWOT strategic model in analysis: The crisis of the political conduct of ISIS, Islamic Republic of Iran and ways to get out of it. Islamic Politics Research, 3, 81-106.

Singh, M. (2012). China's strategic petroleum reserves: A reality check. Institute for Defence Studies and Analyses (IDSA), Issue Brief. https://idsa.in/system/files/IB_ChinasStrategicPetroleumReserves_MandipSingh_210512.pdf.

Statista. (2021, June 07). Average annual Brent crude oil price from 1976 to 2021. Retrieved June 20, 2021, from https://www.statista.com/statistics/262860/uk-brent-crude-oil-price-changes-since-1976/

Tunsjø, Ø. (2013).Security and profit in China's energy policy: Hedging against risk. NewYork: Columbia University Press. https://doi.org/10.7312/columbia/9780231165082.001.0001

Wang, C. N. (2021). China's investments in the Belt and Road Initiative (BRI) in 2020. IIGF Green BRI Center: $1-26$.

Wang, K. H., Su, C. W., \& Umar, M. (2021). Geopolitical risk and crude oil security: A Chinese perspective. Energy, 219, 119555. https://doi.org/10.1016/j.energy.2020.119555

Wang, S. (2020, September 29). Clean energy does not end the energy security game - It reshuffles the deck. The Breakthrough Institute. Retrieved July 10, 2021, from https://hebreakthrough.org/issues/energy/clean-energy-security

Wood Mackenzie. (2020, March 23). China's crude reserves to reach 1.15 billion barrels in 2020. Retrieved October 10, 2020, from https:/www.woodmac.com/press-releases/chinas-crude-reserves-to-reach-1.15-billion-barrels-in-2020/

Wu, A., Hong, K., \& Chung, K. (2020). The impact of COVID-19 on Belt and Road Initiative infrastructure and construction projects. Norton Rose Fulbright-International arbitration report, 14. Retrieved September 30, 2020, from https://www.beltandroad.news/2020/08/01/impact-of-covid-19-on-belt-road-initiative/

Wu, L. (2012). The oil politics \& geopolitical risks with China "going out" strategy toward the greater Middle East. Journal of Middle Eastern and Islamic Studies (in Asia), 6, 59. 
https://doi.org/10.1080/19370679.2012.12023208

Xie, H. (2021). China's oil security in the context of energy revolution: Changes in risks and the hedging mechanism. American Journal of Industrial and Business Management, 11, 984-1008. https://doi.org/10.4236/ajibm.2021.119060

Xinhua Net. (2019, July 31). Economic watch: China welcomes overseas participation in oil, gas exploration. Retrieved June 28, 2021, from http://www.xinhuanet.com/english/2019-07/31/c_138272804.htm

Xu, M., Kelly, S., \& Obayashi, Y. (2020, June 03). China drives global oil demand recovery out of Coronavirus collapse. Reuters. Retrieved June 21, 2021, from https://www.reuters.com/article/idUSKBN23A0XF

Xu, X. (2007, March). Chinese NOCs'overseas strategies: Background, comparision and remarks. Retrieved May 25, 2021, from https://www.bakerinstitute.org/media/files/page/94235e0c/noc_chinesenocs_xu.pdf

Yang, X. (2004). Chinese oil strategy's southwestern orientation. Contemporary Asia-Pacific: 13.

Yergin, D. (2006). Ensuring energy security. Foreign affairs, 85(2), 69-82. https://doi.org/10.2307/20031912

Zhang, H., \& Li, X. (2020). China scales up strategic oil reserves amid Coronavirus-driven global price slump. Global Times. Retrieved August 25, 2020, from https://www.globaltimes.cn/content/1186303.shtml

Zhang, J., King, R., \& Jeffery, C. (2021, June 01). The Belt and Road Initiative 2021 survey - The impact of Covid-19 on the BRI. Retrieved June 30, 2021, from https://www.centralbanking.com/central-banks/economics/7835241/the-belt-and-road-initiative-2021-surve y-the-impact-of-covid-19-on-the-bri

Zhu, K., \& Sharma, N. (2020, April 24). China further opens oil and gas upstream to foreign investors: How much impact can we expect? IHS Markit. Retrieved August 26, 2020, from https://ihsmarkit.com/research-analysis/china-further-opens-oil-and-gas-upstream-to-foreign-investors.html

Zhu, T., \& Wang, L. (2020). State energy transition: German and American realities and Chinese choices. Springer Nature Singapore Pte Ltd. https://doi.org/10.1007/978-981-32-9499-8

\section{Notes}

Note 1. INDC, Intended Nationally Determined Contributions, are non-binding national plans and actions in response to climate change, which contribute to the achievement of global targets set in the Paris Agreement. (Source: World Source Institute: https://www.wri.org/indc-definition.)

Note 2. JV requirement means that the foreign investment in upstream oil and gas exploration and exploitation must be in form of equity joint venture or cooperative joint venture.

\section{Copyrights}

Copyright for this article is retained by the author(s), with first publication rights granted to the journal.

This is an open-access article distributed under the terms and conditions of the Creative Commons Attribution license (http://creativecommons.org/licenses/by/4.0/). 